\title{
Temperature Data Analysis of Diphtheria-Tetanus-Pertussis and Hepatitis B Vaccine Cold Chain Monitoring in Northern Part of Thailand
}

\author{
Kannika Thiankhanithikun ${ }^{1, *}$, Nopphadol Chalortham ${ }^{1}$ and Siriporn Wohbah ${ }^{2}$ \\ ${ }^{1}$ Faculty of Pharmacy, Chiang Mai University, Chiang Mai, Thailand \\ ${ }^{2}$ National Health Security Office (NHSO) Region 1, Chiang Mai, Thailand
}

\begin{abstract}
Background Information: Vaccines are temperature-sensitive biological preparations, the proper range were cold chain period or $2-8{ }^{\circ} \mathrm{C}$. The change of the temperature or cold chain breakdown might be effect to vaccines quality assurance.

Aim: The temperature data of Diphtheria-Tetanus-Pertussis and Hepatitis B vaccine, DPT- HB vaccine in fiscal year 2011-2012 were analyzed and aimed to find the factor that effected to vaccine cold chain system.

Method: Temperature data from health care units in 8 provinces collected by computerized data logger were analyzed by SPSS for window version 17.0 and Logtag analyzer program.

Result: From 322 health care units, most of data was reported from Chiang Rai province and collected from Primary Care Unit; PCU in both fiscal year. The period of time for recording of the data logger were very fluctuates. The highest number of data was reported in October, 2011 and in February, 2012. DPT-HB vaccine temperature had lower than $2^{\circ} \mathrm{C}$ at $86.9 \%$, higher than $8^{\circ} \mathrm{C}$ at $90.4 \%$ in 2011 , and lower than $2^{\circ} \mathrm{C}$ at $78.5 \%$, higher than $8^{\circ} \mathrm{C}$ at $92.5 \%$ in 2012 . Type of health care unit did not effect to vaccine's temperature monitor but seasonal had significant effect.

Conclusion: Type of health care unit did not effect to vaccine's temperature control. Seasonal had significant effect to vaccine's temperature control. Based on the study results, adequate equipment, provide training and supervision about new and current computerize data logger were recommended to support to maximize the efficacy and effectiveness of vaccine and cold chain monitoring in health care unit.
\end{abstract}

Keywords: Vaccine, cold chain, computerized data logger, health care unit, temperature.

\section{INTRODUCTION \& BACKGROUND}

Vaccines are temperature-sensitive biological products that stimulate the immune system of the recipient, whether human or animal, to immunize against pathogens, toxins, or biomolecules, which can reduce or prevent disease. The system used for storing vaccines in good condition is called the cold chain. The objective of the vaccine cold chain is to maintain product quality from the time of manufacture until the point of administration by ensuring that vaccines are stored and transported within World Health Organization-WHO recommended temperature ranges. To maintain efficacy, vaccines must be protected from temperature extremes. Vaccine quality is maintained using a cold chain that meets specific temperature requirements. At the health facility level, WHO recommend that health workers can adequately protect vaccines by keep vaccines in appropriate vaccine refrigeration equipment, use a temperature monitoring device to ensure temperatures remain between $+2{ }^{\circ} \mathrm{C}$

*Address correspondence to this author at the Faculty of Pharmacy, Chiang Mai University, Suthep Road, Amphur Muang, Chiang Mai, 50200, Thailand; Tel: 6653-944351; E-mail: kannika.th@cmu.ac.th and $+8{ }^{\circ} \mathrm{C}$, transport vaccines to immunization sessions in a vaccine carrier, correctly packed, using coolant packs that have been properly prepared,and during immunization sessions, fit a foam pad (if available) at the top of the vaccine carrier.

Diphtheria-Tetanus-Pertussis (whooping cough) and Hepatitis $B$ vaccine, DPT- HB vaccine confers immunity to four different infectious diseases, diphtheria, tetanus, pertussis and hepatitis B. Diphtheria is a potentially fatal disease that usually involves the nose, throat, and air passages. Its most prominent feature is the formation of a grayish membrane covering the tonsils and upper part of the throat. It is caused by Corynebacterium diphtheriae. Tetanus, or lockjaw, is a disease caused by the toxin of Clostridium tetani, affects the central nervous system and causes painful muscle contractions. Tetanus is often fatal. Pertussis, or whooping cough, is a respiratory disease caused by Bordatella pertussis, with a typical cough which starts with a deep inhalation, followed by a series of quick, short coughs that continues until the air is expelled from the lungs, and ends with a long shrill, whooping inhalation. Pertussis is very contagious and usually affects young children. Hepatitis is an inflammation of

@ 2019 SET Publisher 
the liver that can be self-limiting or can progress to fibrosis (scarring), cirrhosis or liver cancer. Hepatitis B virus (HBV) is transmitted through exposure to infective blood, semen, and other body fluids. HBV can be transmitted from infected mothers to infants at the time of birth or from family member to infant in early childhood. Safe and effective vaccines are available to prevent HBV. DPT- HB vaccine which is labeled for storage in cold chain system, between +2 and $+8^{\circ} \mathrm{C}$.

\section{Aims}

This descriptive study was to analyze the data temperature of DPT- HB vaccine in cold chain system. We aimed to find the factor that effected to the change of vaccine's temperature before used, such as area of vaccine transport, seasonal and type of health care unit.

\section{Scope of Study}

Temperature data of DPT- HB vaccine that supplied to health care units in National Health Security Office (NHSO) Region 1 area, included 8 provinces in northern part of Thailand in fiscal year 2011-2012, in the period of October 2011 - September 2013, were analyzed.

\section{METHODS}

The temperature data were collected by computerized data logger and analyzed by SPSS for window version 17.0 and Logtag analyzer program.

\section{Definition}

Vaccine means temperature-sensitive biological products that stimulate the immune system of the recipient to immunize against pathogens, toxins, or biomolecules, which can reduce or prevent disease.

Cold chain means the system used for storing vaccines in good condition, to maintain vaccine quality from the time of manufacture until the point of administration.

Data logger mean electronic devices which automatically monitor and record environmental parameters over time, allowing conditions to be measured, documented, analysed and validated. The data logger contains a sensor to receive the information and a computer chip to store it. Then the information stored in the data logger is transferred to a computer for analysis. In this study, Data logger means LogTag Trix-8.

Vendor Managed Inventory (VMI) mean optimizing Supply Chain performance in which the manufacturer is responsible for maintaining the distributor's inventory levels. The manufacturer has access to the distributor's inventory data and is responsible for generating purchase orders.

Primary Care Unit (PCU) means smallest unit of health care that provide primary care for villagers.

Contracting Unit for Primary Care (CUP) mean main Contractor of Primary Care Unit

DPT-HB vaccine mean vaccine that conveys immunity to four different infectious diseases, diphtheria, tetanus, pertussis and hepatitis B.

Seasonal means summer in the period from March to June, rainy in the period from July to October and winter in the period from November to February.

Table 1: Number of Primary Care Unit and Contracting Unit for Primary Care in each Province and Number of Data Reported to NHSO. In Fiscal Year 2011-2012

\begin{tabular}{|c|c|c|c|}
\hline \multirow{2}{*}{ Province } & Number of health care units with data & \multicolumn{2}{|c|}{ Temperture data } \\
\cline { 3 - 4 } & logger & Number & 40.0 \\
\hline \hline Chiang Rai & 214 & 6 & 12.2 \\
\hline Mae Hong Son & 49 & 41 & 30.6 \\
\hline Lampang & 134 & 21 & 40.4 \\
\hline Lamphun & 52 & 57 & 15.3 \\
\hline Chiang Mai & 373 & 36 & 40.0 \\
\hline Phayao & 90 & 55 & 39.0 \\
\hline Nan & 141 & 27 & 18.6 \\
\hline Phrae & 145 & 322 & 26.9 \\
\hline Total & 1,198 & & \\
\hline
\end{tabular}




\section{RESULTS AND DISCUSSION}

Temperature data of DPT- HB vaccine that supplied to health care units in National Health Security Office (NHSO) Region 1 area, included 8 provinces in northern part of Thailand, Chiang Mai, Chiang Rai, Lampang, Mae Hong Son, Phrae, Nan, Lamphun and Phayao Province, were analyzed.

Table 1 shows that 1,198 health care units that used data logger with 322 health care units sending data back to National Health Security Office (NHSO) Region 1 area, return rate of data was $26.9 \%$, most of data that sending back to National Health Security Office (NHSO) Region 1 area at $40.4 \%$ from health care units in Lamphun province and the last that the data from health care units in Mae Hong Son province at $12.2 \%$.
General information of Contracting Unit for Primary Care; CUP and Primary Care Unit; PCU with data logger and number of data in fiscal year 2011-2012 by province and month were shown in Table 2. Most temperature data was collected from Primary Care Unit; PCU and from Chiang Rai province in both fiscal year. The highest number of temperature data was reported in October of fiscal year 2011 and in February of fiscal year 2012 .

Table 3 shows varies time period for setting data logger, most at the period of 1 hour, in fiscal year 2011, DPT-HB vaccine temperature had lower than $2^{\circ} \mathrm{C}$ at $86.9 \%$, higher than $8^{\circ} \mathrm{C}$ at $90.4 \%$ and in fiscal year 2012, DPT-HB vaccine temperature had lower than $2^{\circ} \mathrm{C}$ at $78.5 \%$, higher than $8^{\circ} \mathrm{C}$ at $92.5 \%$.

Table 2: General information of Contracting Unit for Primary Care; CUP and Primary Care Unit; PCU with Data Logger

\begin{tabular}{|c|c|c|c|c|}
\hline \multirow[t]{2}{*}{ General information } & \multicolumn{2}{|c|}{2011} & \multicolumn{2}{|c|}{2012} \\
\hline & Frequency & Percent & Frequency & Percent \\
\hline \multicolumn{5}{|l|}{ Number of data from Data logger from } \\
\hline Contracting Unit for Primary Care; CUP & 31 & 9.6 & 105 & 7.5 \\
\hline Primary Care Unit; PCU & 292 & 90.4 & 1294 & 92.5 \\
\hline \multicolumn{5}{|l|}{ Number of data from Data logger in province } \\
\hline Chiang Rai & 58 & 17.9 & 358 & 25.6 \\
\hline Mae Hong Son & 35 & 10.8 & 31 & 2.2 \\
\hline Lampang & 39 & 12.1 & 185 & 13.2 \\
\hline Lamphun & 29 & 9.0 & 83 & 5.9 \\
\hline Chiang Mai & 35 & 10.8 & 270 & 19.3 \\
\hline Phayao & 48 & 14.9 & 183 & 13.1 \\
\hline Nan & 50 & 15.5 & 174 & 12.5 \\
\hline Phrae & 29 & 9.0 & 115 & 8.2 \\
\hline \multicolumn{5}{|l|}{ Month } \\
\hline September & 25 & 7.8 & 107 & 7.6 \\
\hline October & 88 & 27.2 & 102 & 7.3 \\
\hline November & 87 & 26.9 & 114 & 8.1 \\
\hline December & 67 & 20.8 & 144 & 10.3 \\
\hline January & 34 & 10.5 & 131 & 9.4 \\
\hline February & 20 & 6.2 & 147 & 10.5 \\
\hline March & 2 & 0.6 & 140 & 10.0 \\
\hline April & 0 & 0 & 135 & 9.7 \\
\hline May & 0 & 0 & 114 & 8.2 \\
\hline June & 0 & 0 & 98 & 7.0 \\
\hline July & 0 & 0 & 49 & 3.5 \\
\hline August & 0 & 0 & 118 & 8.4 \\
\hline
\end{tabular}


Table 3: Data Logger Character of Time Period for Record Temperature and Number of Data Outside cold Chain Period

\begin{tabular}{|c|c|c|c|c|}
\hline \multirow[t]{2}{*}{ Character } & \multicolumn{2}{|c|}{2011} & \multicolumn{2}{|c|}{2012} \\
\hline & frequency & percent & frequency & percent \\
\hline 3 minute & 0 & 0 & 1 & 0.1 \\
\hline 5 minute & 23 & 7.1 & 145 & 10.3 \\
\hline 6 minute & 0 & 0 & 76 & 5.4 \\
\hline 7 minute & 0 & 0 & 77 & 5.5 \\
\hline 10 minute & 8 & 2.5 & 60 & 4.3 \\
\hline 11 minute & 0 & 0 & 55 & 3.9 \\
\hline 20 minute & 0 & 0 & 166 & 11.9 \\
\hline 30 minute & 39 & 12.1 & 252 & 18 \\
\hline 1 hour & 253 & 78.3 & 565 & 40.4 \\
\hline 3 hour & 0 & 0 & 1 & 0.1 \\
\hline 18 hour 8 second & 0 & 0 & 1 & 0.1 \\
\hline \multicolumn{5}{|l|}{ Temperature } \\
\hline Lower than $+2^{\circ} \mathrm{C}$ & 281 & 86.9 & 1,099 & 78.5 \\
\hline Higher than $+8^{\circ} \mathrm{C}$ & 291 & 90.4 & 1,294 & 92.5 \\
\hline
\end{tabular}

Factor Effected to the Change of Vaccine's Temperature

Temperature data outside cold chain period, lower than $2^{\circ} \mathrm{C}$ and higher than $8^{\circ} \mathrm{C}$, by province were shown in Figure $\mathbf{1}$ and $\mathbf{2}$. Relationship between type of health care unit and percent of temperature data lower than $2^{\circ} \mathrm{C}$ and higher than $8^{\circ} \mathrm{C}$, were shown in Tables 4 and 5.

Figure 1 and 2 show temperature data outside cold chain period, lower than $2^{\circ} \mathrm{C}$ and higher than $8^{\circ} \mathrm{C}$, by province.
Percent of temperature data lower than $2^{\circ} \mathrm{C}$ of Contracting Unit for Primary Care; CUP was significantly different from percent of temperature data of Primary Care Unit; PCU in fiscal year 2012, $p=0.001$, but did not significantly in fiscal year 2011, $p=0.335$.

Percent of temperature data higher than $8^{\circ} \mathrm{C}$ of Contracting Unit for Primary Care; CUP did not significantly different from percent of temperature data of Primary Care Unit; PCU in both fiscal year 2011, and 2012 ( $p=0.747$ and 0.073 respectively)

Focus on seasonal effect to vaccine temperature control, the result show that in fiscal year 2011, percent

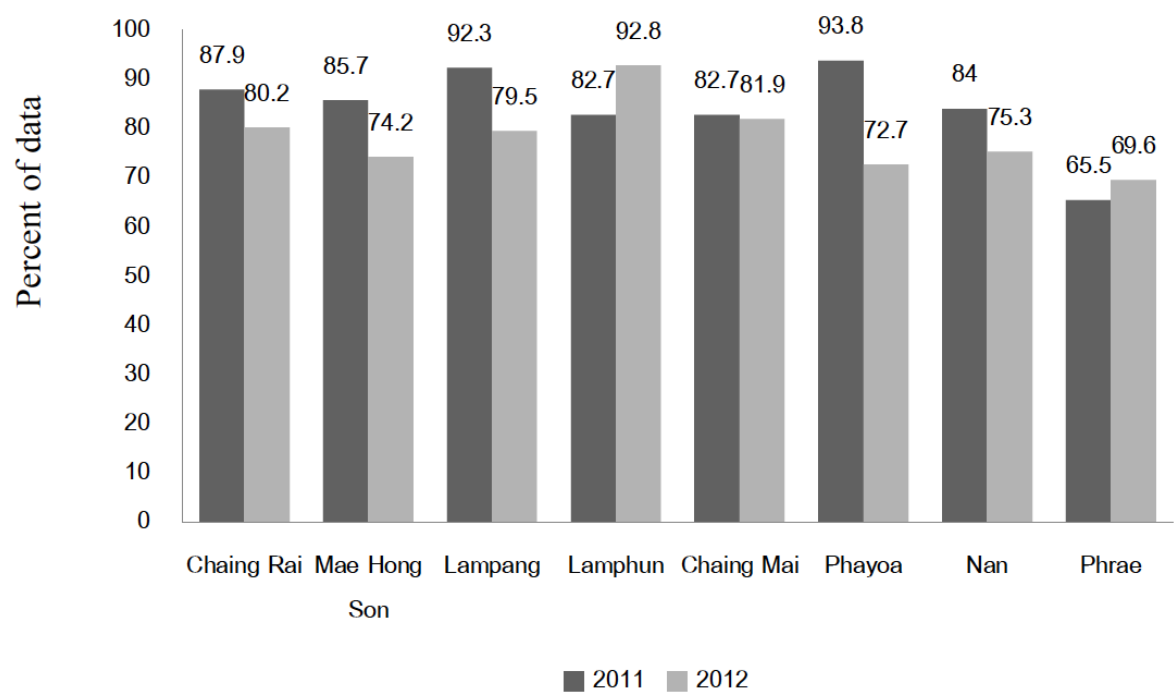

Figure 1: Percent of temperature data lower than $2^{\circ} \mathrm{C}$ by province. 


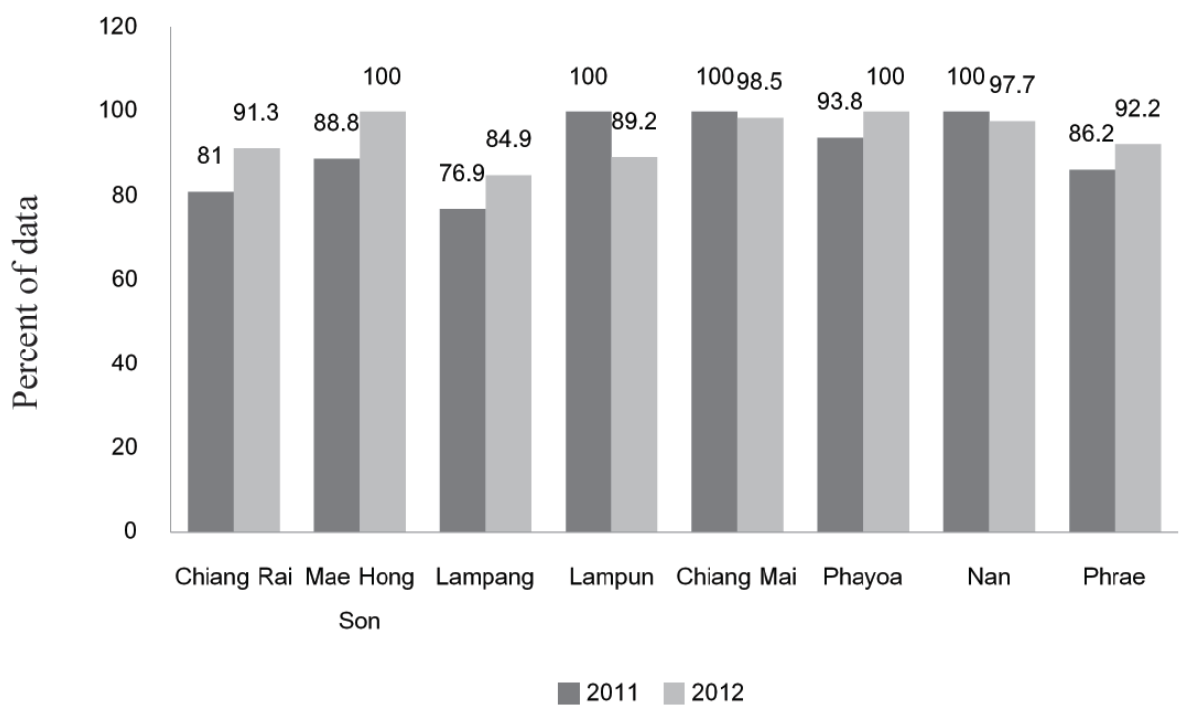

Figure 2: Percent of temperature data higher than $8^{\circ} \mathrm{C}$ by province.

Table 4: Relationship between Type of Health Care Unit and Percent of Temperature Data Lower than $2^{\circ} \mathrm{C}$

\begin{tabular}{|c|c|c|}
\hline Type of health care unit & Median (interquartile range) & P-value \\
\hline \multicolumn{3}{|l|}{ Fiscal year 2011} \\
\hline Contracting Unit for Primary Care; CUP & $2.8(21.2)$ & \multirow[t]{2}{*}{0.335} \\
\hline Primary Care Unit; PCU & $2.9(33.6)$ & \\
\hline \multicolumn{3}{|l|}{ Fiscal year 2012} \\
\hline Contracting Unit for Primary Care; CUP & $0.0(1.3)$ & \multirow[t]{2}{*}{0.001} \\
\hline Primary Care Unit; PCU & $0.9(8.2)$ & \\
\hline
\end{tabular}

*Mann-Whitney U Test.

Table 5: Relationship between Type of Health Care Unit and Percent of Temperature Data Higher than $8^{\circ} \mathrm{C}$

\begin{tabular}{|c|c|c|}
\hline \multicolumn{1}{|c|}{ Type of health care unit } & Median (interquartile range) & P-value* \\
\hline \hline Fiscal year $\mathbf{2 0 1 1}$ & $0.7(11.4)$ & $1.1(8.3)$ \\
\hline Contracting Unit for Primary Care; CUP & 0.747 \\
\hline Primary Care Unit; PCU & $0.3(1.3)$ \\
\hline Fiscal year 2012 Primary Care Unit; PCU & $0.6(3.2)$ & 0.073 \\
\hline
\end{tabular}

*Mann-Whitney U Test.

of temperature data higher than $8^{\circ} \mathrm{C}$ in rainy season was only significantly different from percent of temperature data higher than $8^{\circ} \mathrm{C}$ in winter season, show in Table 6.

In fiscal year 2012, percent of temperature data lower than $2^{\circ} \mathrm{C}$ in summer season was significantly different from percent of temperature data lower than $2^{\circ} \mathrm{C}$ in rainy season, rainy season with winter season and summer season with winter season, show in Tables 7 and 8.
Table 6: Relationship between Percent of Temperature Data Higher than $8^{\circ} \mathrm{C}$ in Rainy and Winter Season in Fiscal Year 2011

\begin{tabular}{|c|c|c|}
\hline Seasonal & median (interquartile range) & P-value $^{*}$ \\
\hline \hline Rainy & $2.4(14.7)$ & 0.001 \\
\hline Winter & $0.6(5.3)$ & \\
\hline
\end{tabular}

*Mann-Whitney U Test.

Percent of temperature data higher than $8^{\circ} \mathrm{C}$ in fiscal year 2012, in rainy season was significantly 
different from percent of temperature data higher than $8^{\circ} \mathrm{C}$ in winter season, $p=0.001$, show in Table 9 and in summer season was significantly different from percent of temperature data higher than $8^{\circ} \mathrm{C}$ in winter season, $\mathrm{p}=0.001$, show in Table 10.

Table 7: Relationship between Percent of Temperature Data Lower than $2^{\circ}$ in Rainy and Winter Season in Fiscal Year 2012

\begin{tabular}{|c|c|c|}
\hline Seasonal & median (interquartile range) & P-value \\
\hline \hline Rainy & $2(24.6)$ & 0.010 \\
\hline Winter & $0.8(8.2)$ & \\
\hline
\end{tabular}

*Mann-Whitney U Test.

Table 8: Relationship between Percent of Temperature Data Lower than $2^{\circ}$ in Summer and Winter Season in Fiscal Year 2012

\begin{tabular}{|c|c|c|}
\hline Seasonal & median (interquartile range) & \multirow{2}{*}{ P-value $^{*}$} \\
\hline \hline Summer & $0.6(3.2)$ & \multirow{2}{*}{0.016} \\
\cline { 1 - 2 } Winter & $0.8(8.2)$ & \\
\hline
\end{tabular}

*Mann-Whitney U Test.

Table 9: Relationship between Percent of Temperature Data Higher than $8^{\circ} \mathrm{C}$ in Summer and Winter Season in Fiscal Year 2012

\begin{tabular}{|c|c|c|}
\hline Seasonal & median (interquartile range) & P-value* \\
\hline \hline Summer & $0.7(3.2)$ & 0.001 \\
\cline { 1 - 2 } Winter & $0.3(2.4)$ & \\
\hline
\end{tabular}

*Mann-Whitney U Test.

Table 10: Relationship between Percent of Temperature Data Higher than $8^{\circ} \mathrm{C}$ in Rainy and Winter Season in Fiscal Year 2012

\begin{tabular}{|c|c|c|}
\hline Seasonal & median (interquartile range) & P-value $^{*}$ \\
\hline \hline Rainy & $0.8(3.3)$ & \multirow{2}{*}{0.001} \\
\hline Winter & $0.3(2.4)$ & \\
\hline
\end{tabular}

${ }^{*}$ Mann-Whitney U Test.

\section{CONCLUSIONS}

Temperature data of DTB-HepB Vaccine from 322 health care units sending back to National Health Security Office (NHSO) Region 1 area in ficalyear 2011-2012, return rate of data was $26.9 \%$. Most of data was from health care units in Chiang Rai province and the last from Mae Hong Son province. Most temperature data was collected from Primary Care Unit; PCU in both fiscal year. The highest number of temperature data was reported in October of fiscal year 2011 and in February of fiscal year 2012. The study also found that most of the health care worker did not set the computerize data logger follow the direction. The period of time for setting data logger were very fluctuates.

In fiscal year 2011, DPT-HB vaccine temperature had lower than $2^{\circ} \mathrm{C}$ at $86.9 \%$, higher than $8^{\circ} \mathrm{C}$ at $90.4 \%$ and in fiscal year 2012, DPT-HB vaccine temperature had lower than $2^{\circ} \mathrm{C}$ at $78.5 \%$, higher than $8^{\circ} \mathrm{C}$ at $92.5 \%$

Percent of temperature data lower than $2^{\circ} \mathrm{C}$ of Contracting Unit for Primary Care; CUP was significantly different from percent of temperature data of Primary Care Unit; PCU in fiscal year 2012, but did not significantly in fiscal year 2011.

Percent of temperature data higher than $8^{\circ} \mathrm{C}$ of Contracting Unit for Primary Care; CUP did not significantly different from percent of temperature data of Primary Care Unit; PCU in both fiscal year 2011 and 2012.

In fiscal year 2011, percent of temperature data higher than $8^{\circ} \mathrm{C}$ in rainy season was only significantly different from percent of temperature data higher than $8^{\circ} \mathrm{C}$ in winter season

In fiscal year 2012, percent of temperature data lower than $2^{\circ} \mathrm{C}$ in summer season was significantly different from percent of temperature data lower than $2^{\circ} \mathrm{C}$ in rainy season, rainy season with winter season and summer season with winter season. Percent of temperature data higher than $8^{\circ} \mathrm{C}$ in rainy season was significantly different from percent of temperature data higher than $8^{\circ} \mathrm{C}$ in winter season and in summer season with winter season.

Both Contracting Unit for Primary Care; CUP and Primary Care Unit; PCU were well developed ability in usage the computerize data logger for monitor cold chain system from fiscal year 2011 to year 2012, especially in the period lower than $2^{\circ} \mathrm{C}$. Seasonal, summer, rainy and winter, had significantly effect to vaccine's cold chain system, especially break down to higher than $8^{\circ} \mathrm{C}$, the same direction both in fiscal year 2011 and 2012.

Based on the study results, adequate equipment, provide training and supervision about new and current computerize data logger were recommended to support to maximize the efficacy and effectiveness of vaccine and cold chain monitoring in health care unit. 


\section{REFERENCES}

[1] Department of Immunization, Vaccines and Other Biologicals, World Health Organization. Cold chain, vaccines and safe-injection equipment management. Geneva: WHO 2008.

[2] World Health Organization. The effects of freezing of the appearance, potency and toxicity on adsorbed and unabsorbed DTP vaccines. Weekly Epidemiological Record 1980; 55: 385-392.

[3] Tharmaphornpilas $\mathrm{P}$, Yoocharoan $\mathrm{P}$, Prempree $\mathrm{P}$, Youngpairoj S, Sriprasert P, Vitek CR. Diphtheria in Thailand in the 1990s. J Infect Dis 2001; 184: 1035-40. https://doi.org/10.1086/323453

[4] American Academy of Pediatrics. Tetanus. In: Pickering LK, Baker CJ, Long SS, Kimberlin DW, editorss. Red Book: 2009 Report of the Committee on Infectious Diseases. 28th ed. Elk Grove Village, IL: American Academy of Pediatrics 2009; pp. $555-60$.

[5] Centers for Disease Control and Prevention (CDC). Final reports of internationally notifiablediseases. MMWR Morb Mortal Wkly Rep 2010; 59: 1025,1027-39.

[6] Bisgard KM, Rhodes P, Connelly BL, Bi D, Hahn C, Patrick $\mathrm{S}$, et al. Pertussis vaccine effectiveness among children 6 to 59 months of age in the United States, 1998-2001. Pediatrics 2005; 116: e285-94. https://doi.org/10.1542/peds.2004-2759

[7] Casey JR, Pichichero ME. Acellular pertussis vaccine safety and efficacy in children, adolescents and adults. Drugs 2005; 65: 1367-89. https://doi.org/10.2165/00003495-200565100-00005

[8] Kosuwon $\mathrm{P}$, Warachit $\mathrm{B}$, Hutagalung $\mathrm{Y}$, Borkird $\mathrm{T}$, Kosalaraksa $\mathrm{P}$, Bock $\mathrm{HL}$, et al. Reactogenicity and immunogenicity of reduced antigen content diphtheriatetanus-acellular pertussis vaccine (dTpa) administered as a booster to 4-6 year-old children primed with four doses of whole-cell pertussis vaccine. Vaccine 2003; 21: 4194-200. https://doi.org/10.1016/S0264-410X(03)00496-1

[9] Sänger $R$, Behre $U$, Krause $K H$, Loch HP, Soemantri $P$, Herrmann $\mathrm{D}$, et al. Booster vaccination and 1-year follow-up of 4-8-year-old children with a reduced-antigen-content dTpaIPV vaccine. Eur J Pediatr 2007; 166: 1229-36. https://doi.org/10.1007/s00431-006-0403-x
[10] Langley JM, Predy G, Guasparini R, Law B, Diaz-Mitoma F, Whitstitt $P$, et al. An adolescent-adult formulation tetanus and diphtheria toxoids adsorbed combined with acellular pertussis vaccine has comparable immunogenicity but less reactogenicity in children 4-6 years of age than a pediatric formulation acellular pertussis vaccine and diphtheria and tetanus toxoids adsorbed combined with inactivated poliomyelitis vaccine. Vaccine 2007; 25: 1121-5. https://doi.org/10.1016/j.vaccine.2006.09.053

[11] Meyer CU, Habermehl P, Knuf M, Hoet B, Wolter J, Zepp F. Immunogenicity and reactogenicity of acellular pertussis booster vaccines in children: standard pediatric versus a reduced-antigen content formulation. Hum Vaccin 2008; 4 203-9.

https://doi.org/10.4161/hv.4.3.5290

[12] Scheifele DW, Halperin SA, Ochnio JJ, Ferguson AC, Skowronski DM. A modified vaccine reduces the rate of large injection site reactions to the preschool booster dose of diphtheria-tetanus-acellular pertussis vaccine: results of a randomized, controlled trial. Pediatr Infect Dis J 2005; 24: 1059-66.

https://doi.org/10.1097/01.inf.0000190028.96152.46

[13] Bailleux F, Coudeville L, Kolenc-Saban A, Bevilacqua J, Barreto $L$, André $P$. Predicted long-term persistence of pertussis antibodies in adolescents after an adolescent and adult formulation combined tetanus, diphtheria, and 5component acellular pertussis vaccine, based on mathematical modeling and 5-year observed data. Vaccine 2008; 26: 3903-8. https://doi.org/10.1016/j.vaccine.2008.04.089

[14] Techathawat $S$, Varinsathien $P$, Rasdjarmrearnsook $A$, Tharmaphornpilas $P$. Exposure to heat and freezing in the vaccine cold chain in Thailand. Vaccine 2007; 1328-33. https://doi.org/10.1016/j.vaccine.2006.09.092

[15] Hilary Briggs SI. Weak link in vaccine cold chain. BMJ 1993 306: 557-8. https://doi.org/10.1136/bmj.306.6877.557

[16] Nelson C, Froes p, Dyck AMV, Chavarria J, Boda E, Coca A, et al. Monitoring temperatures in the vaccine cold chain in Bolivia. Vaccine 2007; 433-7. https://doi.org/10.1016/j.vaccine.2006.08.017

[17] Chen D, Tyagi A, Carpenter J, Perkins S, Sylvester D, Guy $M$, et al. Characterization of the freeze sensitivity of a hepatitis B vaccine. Human Vaccines 2009; 5: 26-32. https://doi.org/10.4161/hv.5.1.6494

\section{DOI: https://doi.org/10.29169/1927-5951.2019.09.01.1}

(C) 2019 Thiankhanithikun et al.; Licensee SET Publisher.

This is an open access article licensed under the terms of the Creative Commons Attribution Non-Commercial License (http://creativecommons.org/licenses/by-nc/3.0/) which permits unrestricted, non-commercial use, distribution and reproduction in any medium, provided the work is properly cited. 